\title{
Technical Solution for Protection of Heat Pump Evaporators Against Freezing the Moisture Condensed
}

\author{
Gregory P. Vasilyev ${ }^{1}$, Vitaly A. Leskov ${ }^{2}$, Natalia V. Mitrofanova ${ }^{1}$, Victor F. Gornov ${ }^{1}$, Marina V. Kolesova ${ }^{3}$, Georgiy V. \\ Esaulov ${ }^{4}$, Yuriy A. Tabunshchikov ${ }^{4}$ \\ ${ }^{1} J S C$ «NIIMosstroy», Moscow, Russia, 119192, Moscow, Vinnitskaya Streat, house 8 \\ ${ }^{2} J S C$ «NIIMosstroy», Moscow, Russia, 119192, Moscow, Vinnitskaya Streat, house 8 \\ ${ }^{3} J S C$ «Insolar-Energo», Moscow, Russia, 121433, Moscow, Filevskaya Street, house 32, building 3 \\ ${ }^{4}$ Moscow Architectural instiute (State Academy), Moscow, RozhdestvenkaStreet, house 11/4
}

\begin{abstract}
This article is dedicated to the study of the processes of formation and freezing of condensate in heat exchangers using ambientair heat and is prepared according to the results of experimental investigations. The aim of this work has been set to elaboratean energy-independent technical solution for protection of heat-exchange equipment against freezing the moisture condensed on the heat-exchange surfaces while using the low-potential heat of ambient air in heat pump systems. The investigations have shown that at the temperatures of ambient air close to $0^{\circ} \mathrm{C}$ when using the "traditional» way of defrostation, which means the reverse mode of operation of heat pump, an intensive formation of ice is observed at the bottom part of evaporator (if not provided with tray heater). This effect is provoked by downward flow of thawed waterand it'sfreezing in the lower part of the heat-exchanger due to the fact that the tray and housing of heat pump have a temperature below zero. Thereafter, while the defrostation mode has been periodically used, the ice coat would begoing to continue its growth,and by time significant area of evaporator could appear to be covered with ice.The results of the investigations presented in the article could be applied both to air-source heat pumps and to ventilation air heat recuperators
\end{abstract}

\section{Introduction}

The problem of condensation and subsequent freezing of moisture on the surfaces of the heat exchange equipment cooled down to negative temperatures and using the low-potential heat of ambient air is one of the main technical obstacles on the way to wide application of air-source heat pumps in countries with cold climate. The technical problems are bound up with the frost formation and icing of the heat-exchange surfaces and, as a consequence, with a fast decrease of the efficiency of heat pump equipment. The very same problems are observed in recuperative heat exchangers of ventilation systems [1, 2].The most popular solution of the problem of frost formation on heat-exchange surfaces today is their defrostationby the periodical heating of the iced surfaces and their purification from frost and ice [1, 2].But this technology demands of essential energy expenditures. An alternative method of protection of heat-exchange surfaces against icing is the protection by the chemical method, by bringing of a special structure onto the heatexchange surface. The principle of action of all the anti-icing structures is based on their heightened hydrophoby, in other words, they do not sorb on their own surfaces water and it's vapors. Numerous works, for example, patent [3] and work [4], affecting the problem of creating of anti-icing coatings, as the main ingredient offer the organosilicon compounds.

In work [5], the main methods of combating against icing for different technical systems are presented with the accent on the chemical methods, andactual examples of elaborations for these subjects are brought. In work [6], the questions are lit up about combating against icing of different radiotechnical equipment and the decisions based on bringing of different chemical structures onto the surface of antennas and so on are offered. The analysis of the published methods and ways of protection of surfaces against icing shows that for the protection of heat-exchange surfaces against

\footnotetext{
Corresponding author: eco-insolar@mail.ru
} 
frost formation and icing the most energetically effective method is to bring onto the heatexchange surface of hydrofobe compounds which prevent from moistening the surface with water and from formation of frost. The investigations presented in this article are devoted to namely this topic.

\section{Experimental study of the process of frostin-up Pf heat-exchange equipment}

The authors of this article have conducted a complex of investigations directed to the elaboration of energyindependent technical solutions for protection of heatexchange equipment against freezing of condensed moisture while utilizingambient air heat. The experimental works were conducted on air-source heat pump unit with thermal capacity of $15 \mathrm{~kW}$. Thisunit provides the heat supply for a building in Moscow. The evaporator is made of finned copper tubes and fin spacingis $2.5 \mathrm{~mm}$.

Fig. 1 represents a typical view of frost formation on the evaporator of an air-sourceheat pump.

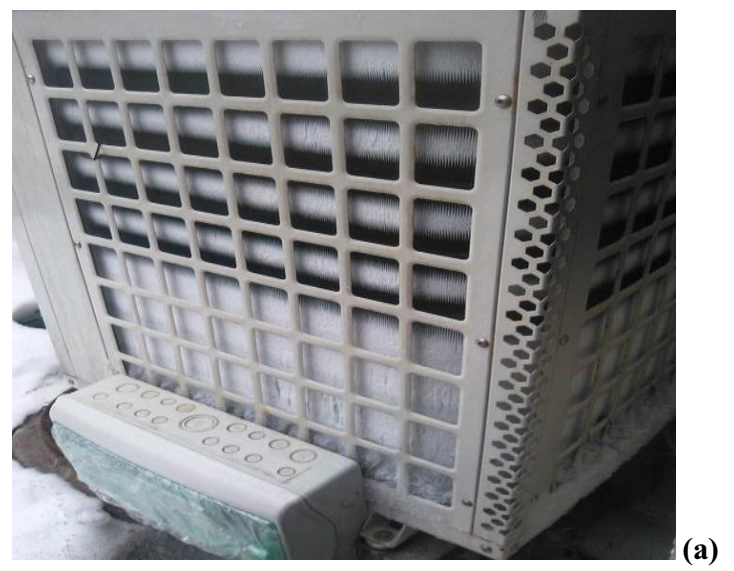

Evaporator Front Part

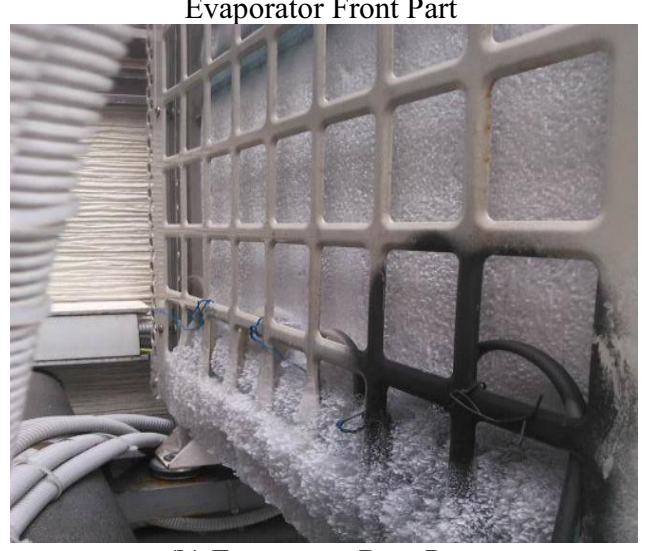

(b) Evaporator Rear Part

Figure 1. Formation of Frost on ASHP Evaporator

The traditional solution for frost removal from the heat-exchanger surface is to put ASHP in revers mode of operation, which provides a short-term heating of the heat-exchanger. The conditions of switching onto defrostation mode are as follows:

1. no less than 40 minutes of the continuous operation of the compressor;

2. Temperature of minus $3^{\circ} \mathrm{C}$ or lower on the evaporator surface is achieved.

When the heat-exchanger surface temperature reaches up to $15^{\circ} \mathrm{C}$, the defrostation mode is over and ASHP returns to its normal operation.

Fig.2 presents the heat-exchanger evaporator surface after the defrostation. The observations of defrostation process were conducted during two days. The climatic parameters and the operational characteristics of ASHP unit during the experiment are indicated in Table 1.

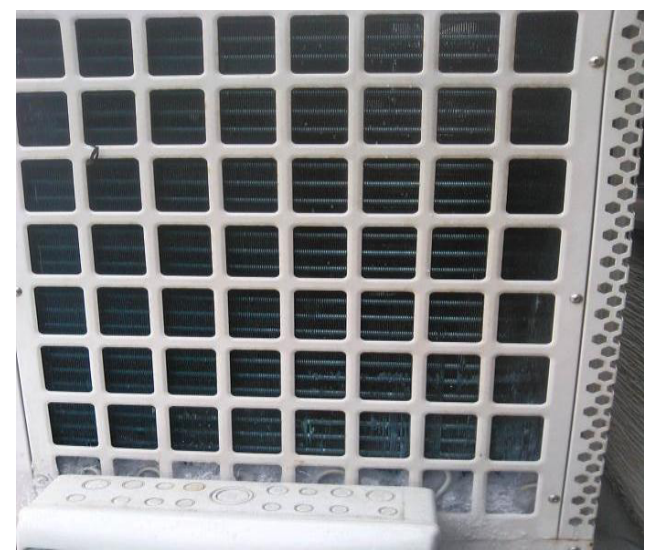

Figure 2. Evaporator After Defrostation

Table 1. Climatic and operational characteristic of ASHP

\begin{tabular}{|c|c|c|c|c|c|}
\hline \multirow{3}{*}{$\begin{array}{c}\text { Parameter } \\
\text { Outdoor air } \\
\text { temperature }\end{array}$} & \multirow{3}{*}{$\begin{array}{c}\begin{array}{c}\text { Unit of } \\
\text { measure } \\
\text { ment }\end{array} \\
{ }^{\circ} \mathrm{C}\end{array}$} & \multicolumn{4}{|c|}{ Date of measurements } \\
\hline & & $\begin{array}{c}27.02 . \\
2015\end{array}$ & \multicolumn{3}{|c|}{02.03 .2015} \\
\hline & & 2,4 & 0,8 & 1,7 & 2,2 \\
\hline $\begin{array}{l}\text { Air relative } \\
\text { humidity }\end{array}$ & $\%$ & 72 & 81 & 76 & 76 \\
\hline Dew point & ${ }^{\circ} \mathrm{C}$ & $-2,13$ & - & $-2,07$ & 1,59 \\
\hline $\begin{array}{c}\text { Coolant } \\
\text { evaporation } \\
\text { temperature }\end{array}$ & ${ }^{\circ} \mathrm{C}$ & -7 & -10 & -10 & -10 \\
\hline Frost presence & & yes & yes & yes & yes \\
\hline $\begin{array}{c}\text { Coolant } \\
\text { condensation } \\
\text { temperature }\end{array}$ & ${ }^{\circ} \mathrm{C}$ & 32 & 42 & 38 & 34 \\
\hline $\begin{array}{l}\text { Heating } \\
\text { capacity }\end{array}$ & $\mathrm{kW}$ & 10 & 8,1 & 10,8 & 11 \\
\hline COP & & 3,1 & 1,8 & 2,4 & 2,6 \\
\hline
\end{tabular}

As the experiments have shown, the water from melted frost which runs down the finning into the lower part of the housing do not have enough time to move off away completely and freezes in the tray and bottom part of the housing. In the lower part of the heat-exchanger ice is formed because of the fact that 
the tray and the housing of the ASHP have the negative temperature(if not provided with tray heater). Thereafter, while the defrostation mode has been periodically used, the ice coat would be going to continue its growth, and by time significant area of evaporator could appear to be covered with ice. As a consequence of this fact, a significant decrease of the coefficient of performance (COP) of ASHP takes place. The experiment have shown that the main shortage of this methods of fighting against frost formation is the fact that in conditions, when ambient air temperature is below $5^{\circ} \mathrm{C}$ and its relative humidity is higher than $70 \%$ the operation of ASHP unit inducean increase of the ice crust on the evaporator, what afterwards worsens the heat-exchange efficiency and the characteristics of ASHP as well as increases the risk of damaging of evaporator fins and tubes. In conditions of both negative and low positive temperatures together with high relative humidity of outdoor air, moisture is intensively condensed and the frost is formed on the evaporator of ASHP.For the search of alternative and energy-independent methods of protection of heat-exchange surfaces of evaporators fromfrost and ice formation, study ofthe influence of application of hydrophobic compounds to heat-exchange surface of evaporator is examined. The experiment have been conducted with the following coatings:

Compound 1 - fluid 101 on hydrocarbon basic;

Compound 2 - dry film lubrication on the basis of polytetrafluorethylene (PTFE) Ballistol;

Compound 3 - dry film lubrication on the basic of PTFE Kontaflon 85.

Before bringing agents, the heat-exchange surface was purified and degreased. Coatings had been deposited on the surface of the evaporator by spraying.

\section{Conclusion}

The experimental study of efficiently of different methods of heat-exchange surfaces protection against frost and ice formation at the ambient air temperatures close to $0^{\circ} \mathrm{C}$ has shown thatthe application of the traditional methods of defrostation of ASHP evaporator by reversing its operationresults in an intensive formation of ice crust at the downmost parts of ASHP unit, induced by freezing of water from melted frost which runs down the finning into the lower part of the housing. In the lower part of the heat-exchanger ice is formed because of the fact that the tray and the housing of the ASHP have the negative temperatures(if not provided with tray heater).Thereafter, while the defrostation mode has been periodically used, the ice coat would be going to continue its growth, and by time significant area of evaporator could appear to be covered with ice. As a consequence, the COP decreases and ASHP loses its efficiency. The experiment have shown that the main weakness of this methods of fighting against frost formation is the fact that in conditions, when ambient air temperature is below $5{ }^{\circ} \mathrm{C}$ and its relative humidity is higher than $70 \%$ the operation of ASHP unit inducegrowth of ice crust on the evaporator, what afterwards worsens the heat-exchange efficiency and the characteristics of ASHP as well as increases the risk of damaging of evaporator fins and tubes [7].Experiments, dedicated to study of moisture removal from the heat-exchange surface have shown, that:

On the section of the heat-exchange surface treated with hydrofobe compound 1 on the hydrocarbon basis, the area of formation of frost is approximately $30 \%$ less than the same of untreated sections of the surface;

The sections of the heat-exchange surface treated with hydrofobe agents on the basis of polytetrafluorethybene (PTFE or Teflon), if compared to untreated surface, show no differencein frost formation;

on the section of the heat-exchange surface treated with water-repellent compounds, the effect of enlargement of moisture drops and their further freezing in the space between fins of the evaporator has been noticed. This phenomenon could be explained if considering that during deposition of compound some spots were not covered with it, while neighboring regions were. In this case droplets of water could stuck at these spots, held back from descending by hydrofobe surroundings, especially if their weight is not sufficient to overcome both capillary and waterrepellent effects working together.

\section{Acknowledgement}

The Research was conducted by JSC "NIIMosstroy" with the financial support of the Ministry of Education and Science of Russia. Unique identifier of the project RFMEFI57914X0081.

\section{References}

1. G.P.Vasilyev, N.A. Timofeyev «Energy Potential of Ventilation Effluents of Dwelling Houses in Moscow» ABOK: Ventilation, Heating, Air Conditioning, Heat Supply and Building Thermal Physics. 2010, № 1 .

2. G.P. Vasilyev «Results of Nature Investigations of the Heat Regime of an Experimental Energy- 
Effective Building» Building materials, Equipment, Technology of 21 age. 2002 №6, page 6.

3. E.B. Aleskovskaya Ya. A. Dybinsky, V.V. Tokarev, Patent 2162872 RF. MPK C09K3/18 Hydrofobe Anti-Icing Composition.

4. Polymeric Roofing and Hydraulic Insulating Materials. Edited by Shulzhenko Yu.P. - M., VNIIESM. 1993.

5. N.S. Shorina,V.V. Smogunov, Problem of Ice Formation and Short Survey of Modern Methods of Struggle against It // Proceedings of the International Symposium «Reliability and Quality». - 2010. - Vol.2. Pages 91-93.
6. N.S. Kornoukhova, V.A. Krotikov., Z. N., Krasilnikova,S.V. Chuppinova,N.V. Shnurkov, Application of Anti-Icing Coating for RadioTechnical Equipments. - Annex «Technologies Equipment Materials» to the Periodical «Economics and Production» № 7 July, 1999.

7. G.P. Vasilyev,N.V. Peskov,M.M. Brodach, V.A. Lichman,A.N. Dmitriev,V.F. Gornov., M.V. Kolesova,I.A. Yurchenko «Ground Moisture Condensation around the GSHP Borehole» Applied Mechanics and Materials Vol.664, 2014 p. 236-242. 